\title{
FII HAEMAGGLUTINATION TEST FOR SERUM ANTIGAMMAGLOBULIN FACTORS IN STILL'S DISEASE
}

\author{
BY \\ D. W. ZUTSHI, B. M. ANSELL, E. G. L. BYWATERS, W. V. EPSTEIN, \\ E. J. HOLBOROW, AND C. A. READING \\ MRC Rheumatism Research Unit, Canadian Red Cross Memorial Hospital, Taplow, Maidenhead, Berks.
}

The nosological status of Still's disease (juvenile chronic polyarthritis) in relation to adult rheumatoid arthritis has been widely debated; one of the major differences is the markedly lower frequency of rheumatoid factor in the former even at low titres. Bywaters, Carter, and Scott (1959) reported that only 13.4 per cent. of 142 patients had a positive Waaler-Rose or differential agglutination test (DAT) of $1: 16$ or more on initial testing. Cassidy and Valkenburg (1967), using the human erythrocyte agglutination test and the latex-fixation test, showed 22 per cent. of 110 patients with juvenile rheumatoid arthritis of onset before the age of 15 years to be positive by one or other test. In the largest published series, Laaksonen (1966) showed that the latex-fixation test was positive in 29.5 per cent. of 363 cases and the Waaler-Rose in $11 \cdot 2$ per cent. of 384 cases; and, further, that positivity in either test was more common in cases in which the age at onset was over 6 years.

The FII test, in which tanned sheep erythrocytes coated with human gammaglobulin (Cohn Fraction II) provide the reagent, has proved more sensitive for detecting serum antiglobulin factors than either the DAT or the latex test. Zutshi, Reading, Epstein, Ansell, and Bywaters (1969) showed that 87 per cent. of cases of classical or definite rheumatoid arthritis gave FII test titres of 1:200 or more, compared with 75 per cent. positive by the latex test. The mean titres in Still's disease were significantly, though not markedly, higher than in the control sera. In the present report, the FII test results in Still's disease are analysed in detail and correlated with results of other serological tests and with the clinical state.

\section{Material}

During an 18 month period from May, 1966, to December, 1967, sera were obtained from all new cases fulfilling our criteria for definite Still's disease (Ansell and Bywaters, 1959) and from cases attending for follow-up in whom the diagnosis had previously been substantiated. There was a total of 286 such patients. In addition there were 38 patients designated as "probable" Still's disease (Ansell and Bywaters, 1962); these were cases in which Still's disease seemed the most likely diagnosis but in which our criteria for definite disease were not fulfilled. Control sera were obtained from 203 patients who had recovered from rheumatic fever and were being followedup over a prolonged period, and from seventy sick children not suffering from rheumatic disorders. Since results in these two groups did not differ significantly from each other or from those in other control groups (Zutshi and others, 1969), they will now be considered together. The age distribution of the combined control group was comparable with those under study (Zutshi and others, 1969).

\section{Methods}

The FII haemagglutination test (Heller, Jacobson, Kolodny, and Kammerer, 1954) was performed and evaluated by the techniques described previously (Zutshi and others, 1969). In the FII test sera were titrated over a range of doubling dilutions from $1 / 25$ to $1 / 12,800$ as described above. To obtain mean titres for comparison of different groups of subjects, the tubes in this dilution range were numbered consecutively from 1 to 10 , and the titres of individual sera scored as tube numbers $(0=<1 / 25$, $1=1 / 25,2=1 / 50 \ldots$. . ). The geometric mean FII titres (MFT) and their variances were calculated on this basis of tube numbers. As before, the DAT and the latex-fixation test were also carried out by the methods described by Bywaters and Scott (1960) on the same specimen of serum and at the same time. In addition an immunofluorescence test for antinuclear factor using calf thyroid sections (Holborow and Johnson, 1967) was performed on the same specimen in 211 cases of Still's disease and 31 cases of probable Still's disease. 


\section{Results}

(1) Still's Disease v. Control Subjects (Table I)

The mean FII tube titre (MFT) of $2 \cdot 3$ in the 286 patients with definite Still's disease is significantly higher $(P=<0.001)$ than that of the control subjects $(1 \cdot 6)$, but does not approach that of adult rheumatoid arthritis (7-4). "Probable" Still's disease has a slightly higher mean tube titre $(2 \cdot 0)$ than the controls but does not differ significantly from them $(P=0.4$ to 0.3$)$.

Table II shows that in definite Still's disease the proportion of positive DAT tests was 7 per cent., of positive latex fixation tests 15 per cent. (i.e. twice the frequency) and that of FII titres of $1: 200$ or more 26 per cent., or nearly four times the frequency. As noted above, 87 per cent. of cases of classical or definite rheumatoid arthritis in adults showed titres of $1: 200$ or more, so that the percentage with titres at this level in definite Still's disease is markedly lower, although somewhat higher than in the control group. Probable Still's disease also shows a higher proportion of FII titres of 1:200 or more than of positive latex and DAT tests, but differs even less from the control groups.

\section{(2) Detailed Analysis}

It is clear from the above results that the difference between the cases of definite Still's disease and the control group with respect to antigammaglobulin titres is, although real, relatively small compared with the difference between adult rheumatoid cases and non-rheumatoid control subjects.

One explanation of this might be that the small overall difference noted here conceals a larger difference confined to a subgroup within the definite Still's category. The series, was therefore, further analysed with regard to the following features: sex, activity of disease, age at the time of testing, age at onset of disease, and duration of disease process. The functional status, radiological changes, and certain clinical features at the time of testing were also noted, and the results of antinuclear factor tests considered.

The disease process was considered active when there was tenderness or pain on movement with soft tissue swelling of one or more joints, with or without a raised erythrocyte sedimentation rate (Ansell and Bywaters, 1959).

TABLE I

FII HAEMAGgLUTINATION TITRES IN STILL'S DISEASE, ADULT RHEUMATOID ARTHRITIS, AND CONTROLS

\begin{tabular}{|c|c|c|c|c|c|c|c|c|c|c|c|c|c|c|c|}
\hline \multirow{2}{*}{$\begin{array}{l}\text { No. } \\
\text { of } \\
\text { Cases }\end{array}$} & \multirow{2}{*}{$\frac{\text { FII titre }}{\text { Tube Number }}$} & \multirow{2}{*}{$\frac{<25}{0}$} & \multirow{2}{*}{$\frac{25}{1}$} & \multirow{2}{*}{$\frac{50}{2}$} & \multirow{2}{*}{$\frac{100}{3}$} & \multirow{2}{*}{$\begin{array}{r}200 \\
4 \\
\end{array}$} & \multirow{2}{*}{$\frac{400}{5}$} & \multirow{2}{*}{$\begin{array}{c}800 \\
6 \\
\end{array}$} & \multirow{2}{*}{$\frac{1,600}{7}$} & \multirow{2}{*}{$\begin{array}{c}3,200 \\
8 \\
\end{array}$} & \multirow{2}{*}{$\frac{6,400}{9}$} & \multirow{2}{*}{$\begin{array}{c}12,800 \\
\text { or More } \\
10 \\
\end{array}$} & \multirow{2}{*}{$\begin{array}{l}\text { Mean FII } \\
\text { Tube Titre }\end{array}$} & \multicolumn{2}{|c|}{ Age (yrs) } \\
\hline & & & & & & & & & & & & & & Mean & Range \\
\hline 286 & $\begin{array}{l}\text { Definite } \\
\text { Still's } \\
\text { Disease }\end{array}$ & 142 & 16 & 22 & 30 & 14 & 16 & 13 & 8 & 3 & 8 & 14 & $2 \cdot 3^{*}$ & 18 & $2-55$ \\
\hline 273 & Controls & 142 & 19 & 26 & 38 & 23 & 12 & 5 & 4 & 3 & 1 & - & $1 \cdot 6$ & 20 & $1-48$ \\
\hline 435 & $\begin{array}{l}\text { Classical and } \\
\text { Definite } \\
\text { Rheumatoid } \\
\text { Arthritis }\end{array}$ & 42 & 2 & 7 & 7 & 14 & 20 & 25 & 39 & 65 & 52 & 162 & $7 \cdot 4$ & 53 & $18-81$ \\
\hline 38 & $\begin{array}{c}\text { Probable } \\
\text { Still's } \\
\text { Disease }\end{array}$ & 17 & 3 & 6 & 3 & 4 & 2 & - & 1 & 1 & - & 1 & $2 \cdot 0 t$ & 15 & $5-26$ \\
\hline
\end{tabular}

DAT, LATEX, AND FII HAEMAGGLUTINATION TEST (PER CENT.) IN STILL'S DISEASE AND ADULT RHEUMATOID ARTHRITIS COMPARED WITH CONTROLS

\begin{tabular}{|c|c|c|c|c|c|c|}
\hline \multirow{2}{*}{$\begin{array}{l}\text { No. } \\
\text { of } \\
\text { Cases }\end{array}$} & \multirow{2}{*}{ Group } & \multirow{2}{*}{$\begin{array}{l}\text { DAT } \\
1: 16 \text { or More }\end{array}$} & \multirow{2}{*}{$\begin{array}{l}\text { Latex } \\
+1++\end{array}$} & \multicolumn{3}{|c|}{$\begin{array}{l}\text { FII Haemagglutination Titre } \\
\text { (per cent.) }\end{array}$} \\
\hline & & & & $1 / 200$ or More & $1 / 25-1 / 100$ & $1 / 25$ \\
\hline $\begin{array}{r}286 \\
273 \\
435 \\
38\end{array}$ & $\begin{array}{l}\text { Definite Still's Disease } \\
\text { Controls } \\
\text { Classical and Definite Rheumatoid Arthritis } \\
\text { Probable Still's Disease }\end{array}$ & $\begin{array}{l}7 \\
0 \cdot 4 \\
42 \\
8\end{array}$ & $\begin{array}{r}15 \\
2 \\
75 \\
11\end{array}$ & $\begin{array}{l}26 \\
18 \\
87 \\
23\end{array}$ & $\begin{array}{r}24 \\
30 \\
4 \\
32\end{array}$ & $\begin{array}{r}50 \\
52 \\
9 \\
45\end{array}$ \\
\hline
\end{tabular}


Sex.-In active disease (Table III) the MFT of 2.8 is significantly higher $(\mathrm{P}=<0.001)$ than in the control group, but in inactive disease it is the same $(1 \cdot 6)$. On further analysis according to sex, the MFT and the incidence of FII titres of 1:200 or more in males with active Still's disease is not significantly higher than in male controls $(P=0 \cdot 3$ to $0 \cdot 2$ ), but in the female group of cases of active Still's disease there is a highly significant $(P=<0.001)$ increase in the mean tube titre $(3 \cdot 2)$ compared with both controls and cases of inactive Still's disease. This increase reflects the considerably higher incidence of FII titres of $\mathbf{2 0 0}$ or more in the active female cases compared with the control group. In inactive Still's disease both the males and females give the same MFT and approximately the same distribution of FII titres as in the male and female control groups.

Age at Time of Testing (Table IV).-Active Still's disease shows an increase in MFT with increasing age in both sexes. In males the increase does not occur until the 25 to 34-year age group, but in females it begins in the 10 to 14-year age group. In inactive Still's disease the MFT does not show any obvious increase with increasing age at the time of testing.

Duration of Disease.-This rise in MFT with age is associated more with the age at onset than with the duration of disease. Indeed, when duration only is considered within each age range, no relationship with the MFT is apparent (Table V, overleaf).

Functional Status.-The MFT of patients with no limitation of physical activity at the time of testing (i.e. functional status V) was considerably lower than in those who were incapacitated by severe residual deformity, i.e. functional status II (Table VI). Of the five cases classed in functional status I (i.e. confined to bed), only one was bedfast on account of severe residual deformities and her FII titre was 400 (Tube 5). The other four all had acute illness with systemic manifestations necessitating rest in bed as a temporary measure.

Clinical Features (Table VII).-The MFT in cases of active monoarticular disease was the same as in the control group (see Table I). There was no correlation with the presence of either acute or

TABLE III

FII HAEMAGgLUTINATION TUBE TITRE RELATED TO ACTIVITY OF DISEASE PROCESS AND SEX IN 286 PATIENTS WITH STILL'S DISEASE

\begin{tabular}{|c|c|c|c|c|c|c|c|c|c|c|c|c|c|}
\hline \multirow{3}{*}{ Group } & & \multicolumn{2}{|c|}{ Both Sexes } & \multicolumn{5}{|c|}{ Male } & \multicolumn{5}{|c|}{ Female } \\
\hline & & \multirow{2}{*}{$\begin{array}{l}\text { No. of } \\
\text { Cases }\end{array}$} & \multirow{2}{*}{$\begin{array}{c}\text { Mean } \\
\text { Titre }\end{array}$} & \multirow{2}{*}{$\begin{array}{l}\text { No. of } \\
\text { Cases }\end{array}$} & \multirow{2}{*}{$\begin{array}{l}\text { Mean } \\
\text { Tube } \\
\text { Titre }\end{array}$} & \multicolumn{3}{|c|}{ Per cent. according to Titres } & \multirow{2}{*}{$\begin{array}{l}\text { No. of } \\
\text { Cases }\end{array}$} & \multirow{2}{*}{$\begin{array}{l}\text { Mean } \\
\text { Tube } \\
\text { Titra }\end{array}$} & \multicolumn{3}{|c|}{ Per cent. according to Titre } \\
\hline & & & & & & $\begin{array}{l}1 / 200 \\
\text { or More }\end{array}$ & $1 / 25-1 / 100$ & $<1 / 25$ & & & $\begin{array}{l}1 / 200 \\
\text { or More }\end{array}$ & $1 / 25-1 / 100$ & $<1 / 25$ \\
\hline Still's & & 169 & $2 \cdot 8^{*}$ & 48 & $1 \cdot 9$ & 23 & 19 & 58 & 121 & $3 \cdot 2 \dagger$ & 37 & 21 & 42 \\
\hline Disease & Inactive & 117 & $1 \cdot 6$ & 48 & $1 \cdot 4$ & 10 & 27 & 63 & 69 & $1 \cdot 7$ & 22 & 28 & 50 \\
\hline \multicolumn{2}{|l|}{ Controls } & 273 & $1 \cdot 6$ & 129 & $1 \cdot 4$ & 12 & 36 & 52 & 144 & $1 \cdot 7$ & 23 & 26 & 51 \\
\hline
\end{tabular}

The difference between the mean titres of the male and female controls is not significant $(P=0 \cdot 2-0 \cdot 1)$

TABLE IV

RELATIONSHIP BETWEEN AGE, ACTIVITY OF DISEASE PROCESS, SEX, AND MEAN FII TUBE TITRE

\begin{tabular}{|c|c|c|c|c|c|c|c|c|c|c|c|c|}
\hline \multirow{4}{*}{$\begin{array}{c}\text { Age at Time } \\
\text { of Test } \\
\text { (yrs) }\end{array}$} & \multicolumn{12}{|c|}{ Still's Disease } \\
\hline & \multicolumn{6}{|c|}{ Active } & \multicolumn{6}{|c|}{ Inactive } \\
\hline & \multirow[b]{2}{*}{$\begin{array}{l}\text { Total } \\
\text { Cases }\end{array}$} & \multirow{2}{*}{$\begin{array}{l}\text { Mean } \\
\text { Tube } \\
\text { Titre }\end{array}$} & \multicolumn{2}{|c|}{ Male } & \multicolumn{2}{|c|}{ Female } & \multirow[b]{2}{*}{$\begin{array}{l}\text { Total } \\
\text { Cases }\end{array}$} & \multirow{2}{*}{$\begin{array}{l}\text { Mean } \\
\text { Tube } \\
\text { Titre }\end{array}$} & \multicolumn{2}{|c|}{ Male } & \multicolumn{2}{|c|}{ Female } \\
\hline & & & $\begin{array}{l}\text { No. of } \\
\text { Cases }\end{array}$ & $\begin{array}{l}\text { Mean } \\
\text { Tube } \\
\text { Titre }\end{array}$ & $\begin{array}{l}\text { No. of } \\
\text { Cases }\end{array}$ & $\begin{array}{l}\text { Mean } \\
\text { Tube } \\
\text { Titre }\end{array}$ & & & $\begin{array}{l}\text { No. of } \\
\text { Cases }\end{array}$ & $\begin{array}{l}\text { Mean } \\
\text { Tube } \\
\text { Titre }\end{array}$ & $\begin{array}{l}\text { No. of } \\
\text { Cases }\end{array}$ & $\begin{array}{l}\text { Mean } \\
\text { Tube } \\
\text { Titre }\end{array}$ \\
\hline $\begin{array}{c}0-4 \\
5-9 \\
10-14 \\
15-24 \\
25-34 \\
35-44 \\
45+\end{array}$ & $\begin{array}{r}8 \\
21 \\
54 \\
65 \\
19 \\
2 \\
\end{array}$ & $\begin{array}{l}0 \cdot 4 \\
1 \cdot 5 \\
2 \cdot 4 \\
3 \cdot 5 \\
3 \cdot 8 \\
5 \cdot 5 \\
-\end{array}$ & $\begin{array}{r}3 \\
4 \\
14 \\
18 \\
9 \\
1 \\
-\end{array}$ & $\begin{array}{l}1 \cdot 0 \\
1 \cdot 8 \\
0 \cdot 7 \\
1 \cdot 9 \\
4 \cdot 3 \\
5 \cdot 0 \\
-\end{array}$ & $\begin{array}{r}5 \\
17 \\
40 \\
47 \\
10 \\
1 \\
-\end{array}$ & $\begin{array}{c}0 \\
1 \cdot 3 \\
3 \cdot 0 \\
4 \cdot 1 \\
3 \cdot 3 \\
6 \cdot 0 \\
-\end{array}$ & $\begin{array}{r}1 \\
9 \\
18 \\
59 \\
28 \\
1 \\
1\end{array}$ & $\begin{array}{c}0 \\
1 \cdot 2 \\
1 \cdot 2 \\
1 \cdot 8 \\
1 \cdot 4 \\
1 \cdot 0 \\
4 \cdot 0\end{array}$ & $\begin{array}{r}-2 \\
9 \\
27 \\
10 \\
-\end{array}$ & $\begin{array}{c}\overline{0} \\
1 \cdot 1 \\
1.9 \\
0.5 \\
-\end{array}$ & $\begin{array}{r}1 \\
7 \\
9 \\
32 \\
18 \\
1 \\
1\end{array}$ & $\begin{array}{c}0 \\
1 \cdot 6 \\
1 \cdot 3 \\
1 \cdot 8 \\
1 \cdot 9 \\
1 \cdot 0 \\
4 \cdot 0\end{array}$ \\
\hline
\end{tabular}


TABLE V

MEAN FII TUBE TITRE RELATED TO AGE AT ONSET AND MEAN DURATION OF DISEASE

\begin{tabular}{|c|c|c|c|c|c|c|}
\hline \multirow{3}{*}{$\begin{array}{c}\text { Age at Onset } \\
\text { (yrs) }\end{array}$} & \multicolumn{6}{|c|}{ Still's Disease } \\
\hline & \multicolumn{3}{|c|}{ Active } & \multicolumn{3}{|c|}{ Inactive } \\
\hline & $\begin{array}{l}\text { No. of } \\
\text { Cases }\end{array}$ & $\begin{array}{c}\text { Mean } \\
\text { Tube Titre }\end{array}$ & $\begin{array}{c}\text { Duration } \\
\text { (yrs) }\end{array}$ & $\begin{array}{l}\text { No. of } \\
\text { Cases }\end{array}$ & $\begin{array}{c}\text { Mean } \\
\text { Tube Titre }\end{array}$ & $\begin{array}{c}\text { Duration } \\
\text { (yrs) }\end{array}$ \\
\hline $\begin{array}{c}0-4 \\
5-9 \\
10-14 \\
15\end{array}$ & $\begin{array}{r}45 \\
58 \\
62 \\
4\end{array}$ & $\begin{array}{l}1 \cdot 8 \\
2 \cdot 7 \\
3 \cdot 4 \\
6 \cdot 0\end{array}$ & $\begin{array}{r}10.5 \\
9.7 \\
7.4 \\
11.8\end{array}$ & $\begin{array}{r}39 \\
34 \\
37 \\
7\end{array}$ & $\begin{array}{l}1 \cdot 4 \\
1 \cdot 3 \\
2 \cdot 0 \\
2 \cdot 1\end{array}$ & $\begin{array}{r}13 \cdot 7 \\
13 \cdot 0 \\
9 \cdot 3 \\
10 \cdot 1\end{array}$ \\
\hline
\end{tabular}

TABLE VI

MEAN FII TUBE TITRE AND FUNCTIONAL STATUS

chronic iridocyclitis or of amyloidosis. As might be expected (Zutshi and others, 1969), those with psoriasis and those who had developed ankylosing spondylitis did not have a higher mean tube titre than the controls. Indeed, the only positive clinical correlation was between high FII tube titre and nodules. Two of those with nodules also had vascular lesions and both had titres of $1: 12,800$.

ANF Tests.-Although six out of eleven cases with FII titres of $1: 12,800$ had positive $(1: 10$ or
TABLE VII

MEAN FII TITRE AND CLINICAL FEATURES

\begin{tabular}{|c|c|c|c|c|}
\hline \multirow{3}{*}{ Clinical Features } & \multicolumn{4}{|c|}{ Still's Disease } \\
\hline & \multicolumn{2}{|c|}{ Active } & \multicolumn{2}{|c|}{ Inactive } \\
\hline & $\begin{array}{l}\text { No. of } \\
\text { Cases }\end{array}$ & $\begin{array}{l}\text { Mean } \\
\text { Tube } \\
\text { Titre }\end{array}$ & $\begin{array}{l}\text { No. of } \\
\text { Cases }\end{array}$ & $\begin{array}{l}\text { Mean } \\
\text { Tube } \\
\text { Titre }\end{array}$ \\
\hline $\begin{array}{l}\text { Monarticular onset } \\
\text { Acute and chronic } \\
\text { iridocyclitis at any time } \\
\text { Amyloidosis } \\
\text { Psoriasis } \\
\text { Ankylosing spondylitis } \\
\text { Nodules }\end{array}$ & $\begin{array}{r}10 \\
17 \\
6 \\
2 \\
5 \\
12\end{array}$ & $\begin{array}{l}1 \cdot 6 \\
1 \cdot 1 \\
1 \cdot 3 \\
0 \cdot 5 \\
1 \cdot 0 \\
8 \cdot 4\end{array}$ & $\begin{array}{r}3 \\
\frac{11}{3} \\
2 \\
-\end{array}$ & $\begin{array}{l}0.3 \\
1.9 \\
\frac{0}{2} \\
-\end{array}$ \\
\hline
\end{tabular}

more) ANF tests, no other obvious correlation between ANF and FII titres was found (Table VIII).

Radiographs of the hands, feet, cervical spine, and pelvis were available in all except one of 285 patients with definite and probable Still's disease. Erosive changes include pocketed and surface erosions, while residua include healed lesions, secondary degenerative changes, growth defects, and ankylosis; there was a significantly higher MFT in cases with erosions in whom the disease was still active than in cases with residua only (Table IX). This was also true of

TABLE VIII

ANTINUCLEAR FACTOR AND FII TITRES IN 211 CASES OF DEFINITE AND 31 CASES OF PROBABLE STILL'S DISEASE

\begin{tabular}{l|l|c|c|c|c|c|c|c|c|c|c|c|c|}
\hline & $1: 1,250$ & 6 & 1 & - & 1 & - & - & - & - & - & - \\
ANF Titre & $1: 250$ & 6 & - & - & 2 & - & 1 & - & - & 1 & - \\
\hline $1: 50$ & 10 & - & 1 & 2 & - & - & 1 & - & - & - \\
\hline $1: 10$ & 3 & 1 & 3 & 1 & 1 & - & - & - & - & - & - \\
\hline $1: 10$ & 92 & 12 & 20 & 17 & 14 & 10 & 10 & 6 & 2 & 7 & 5 \\
\hline
\end{tabular}


TABLE IX

MEAN FII TUBE TITRE CORRELATED WITH THE PRESENCE OF RADIOLOGICAL CHANGES

\begin{tabular}{|c|c|c|c|c|c|c|c|}
\hline \multirow{2}{*}{\multicolumn{2}{|c|}{ Still's Disease }} & \multicolumn{2}{|c|}{ Active } & \multicolumn{2}{|c|}{ Inactive } & \multicolumn{2}{|c|}{ Probable } \\
\hline & & $\begin{array}{l}\text { No. of } \\
\text { Cases }\end{array}$ & $\begin{array}{c}\text { Mean } \\
\text { Tube Titre }\end{array}$ & $\begin{array}{l}\text { No. of } \\
\text { Cases }\end{array}$ & $\begin{array}{l}\text { Mean } \\
\text { Tube Titre }\end{array}$ & $\begin{array}{c}\text { No. of } \\
\text { Cases }\end{array}$ & $\begin{array}{l}\text { Mean } \\
\text { Tube Titre }\end{array}$ \\
\hline $\begin{array}{l}\text { Radiological } \\
\text { Changes }\end{array}$ & $\begin{array}{l}\text { Erosions } \\
\text { Residua Only } \\
\text { Nil }\end{array}$ & $\begin{array}{l}92 \\
44 \\
32\end{array}$ & $\begin{array}{l}3 \cdot 9 \\
1 \cdot 8 \\
1 \cdot 4\end{array}$ & $\begin{array}{r}4 \\
82 \\
31\end{array}$ & $\begin{array}{l}1.3 \\
1.9 \\
0.8\end{array}$ & $\begin{array}{r}4 \\
13 \\
21\end{array}$ & $\begin{array}{l}4 \cdot 3 \\
1 \cdot 7 \\
1 \cdot 7\end{array}$ \\
\hline
\end{tabular}

those cases with less than four joints involved and thus classified as probable.

\section{(3) Subsequent Tests}

75 patients with active Still's disease had a further test 6 months after the initial one (Table X). The mean FII tube titre of the second test, $2 \cdot 9$, was similar to the initial value of $3 \cdot 2$. All these patients were on therapy with salicylates and a small number were receiving corticosteroids. There were 22 on gold treatment, and over the 6-month period their mean FII tube titre fell from $5 \cdot 1$ to $3 \cdot 4(P=0 \cdot 1$ to $0.05)$ compared with a slight increase in the 53 cases not on gold (Table $\mathrm{X}$ ).

TABLE X

MEAN FII TUBE TITRE INITIALLY AND AFTER 6 MONTHS IN 75 CASES OF ACTIVE STILL'S DISEASE, RELATED TO GOLD THERAPY

\begin{tabular}{|c|c|c|c|c|}
\hline \multirow{2}{*}{\multicolumn{3}{|c|}{ No. of Cases }} & \multicolumn{2}{|c|}{ Mean FII Tube Titre } \\
\hline & & & \multirow{2}{*}{$\begin{array}{c}\text { Initial } \\
5 \cdot 1^{*} \\
2 \cdot 4^{*}\end{array}$} & \multirow{2}{*}{ 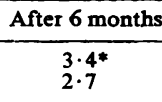 } \\
\hline Gold Therapy & $\begin{array}{l}\text { Yes } \\
\text { No }\end{array}$ & $\begin{array}{l}22 \\
53\end{array}$ & & \\
\hline Total & & 75 & $3 \cdot 2$ & $2 \cdot 9$ \\
\hline
\end{tabular}

\section{Discussion}

It is clear from these results that, even in cases of active Still's disease, the use of a sensitive titration method for serum antiglobulin activity does not greatly increase the rate of sero-positivity. Only 26 per cent. of cases of active Still's disease had titres exceeding $1: 200$ as compared with 87 per cent. of adult cases of rheumatoid arthritis. This difference between juvenile and adult cases may be explained in part by the heterogeneity of the group of patients who initially fulfilled our criteria for a diagnosis of Still's disease (Ansell and Bywaters, 1969). At the time of serological testing, 117 out of 286 of these cases were already inactive; these included two with moderately severe residua and consequent limitation of function, two who had developed ankylosing spondylitis and become inactive, and three who had developed psoriasis (Tables VI and VII). The remainder of the inactive cases, although frequently showing some stigmata of their old Still's disease, had recovered sufficiently to lead normal lives. The patients in whom the disease was still active included five with ankylosing spondylitis and two with psoriasis.

The analysis presented here of anti-gammaglobulin activity in Still's disease shows that the observed excess over control values is largely accounted for by the contribution of female patients with active disease. It is therefore of interest that Jeremy, Schaller, Arkless, Wedgwood, and Healey (1968), reporting on 46 cases of juvenile rheumatoid arthritis studied in adult life (thirty six of whom were female), noted that thirteen ( 28 per cent.) had positive latex tests and that this correlated with an older age at onset. Comparison of mean titres at different ages establishes that the highest level occurs in females between 15 and 25 years of age at the time of testing, and that males do not, on average, reach a similar level for another decade. This association between antiglobulin levels and age in females however, does not relate to duration of disease; instead a clear correlation appears between higher antiglobulin levels and an older age at onset. This is consistent with earlier findings (Ansell, 1965) that, in Still's disease, DAT-positive patients tend to remain positive, while patients initially sero-negative seldom convert to positive. The more frequent occurrence of raised FII titres in females who are older at onset perhaps indicates that this group really represents an early onset of adult rheumatoid arthritis. This idea is supported by the strong association noted between raised FII levels and nodules and/or joint erosions; while the preponderance of females presumably reflects the well-recognized high female/male sex ratio in adult rheumatoid arthritis.

Nevertheless, antiglobulin levels in Still's disease, 
even in the group of active female cases, are far below those found in adult rheumatoid arthritis. The question, therefore, remains whether the discrepancy points to a difference between the mechanisms initiating the disease in juveniles and in adults or whether similar causes engender different degrees of autoimmune response in the two populations.

\section{Summary}

The FII haemagglutination, latex, and differential agglutination tests were performed on 286 patients with definite Still's disease, 38 with "probable" Still's disease, and 273 controls. In definite Still's disease 26 per cent. had an FII titre of 1: 200 or more, 15 per cent. had a positive latex-fixation test, and 7 per cent. a DAT test of $1: 16$ or more. The corresponding figures for controls were 18,2 , and
0.4 per cent. In classical and definite adult rheumatoid arthritis, the figures were 87,75 , and 42 per cent. respectively.

The mean FII tube titre in patients with Still's disease was significantly higher than in the controls $(\mathbf{P}=<0.001)$. This difference correlated particularly with active disease in females, with a later age at onset in both sexes, and with the presence of nodules and erosions.

Severe incapacity, in active or inactive disease, was associated with higher FII titres. Cases with psoriasis, ankylosing spondylitis, monoarticular onset, and acute or chronic iridocyclitis at any time showed no increase in titre. No clear correlation with antinuclear factor was found except in patients with nodules. There was little variation in titre over a period of 6 months, except in patients receiving gold therapy in whom the FII titre fell.

\section{REFERENCES}

Ansell, B. M. (1965). “Still's disease", in "Progress in Clinical Rheumatology", ed. A. St.J. Dixon, p. 95 . Churchill, London.

— and Bywaters, E. G. L. (1959). Bull. rheum. Dis., 9, 189 (Prognosis in Still's disease).

(1962). Ann. rheum. Dis., 21, 253 (Diagnosis of "probable" Still's disease and its outcome).

(1969). "Juvenile chronic polyarthritis or Still's disease", in "Textbook of the Rheumatic Diseases", ed. W. S. C. Copeman, 4th ed., p. 323. Livingstone, Edinburgh.

Bywaters, E. G. L., Carter, M. E., and Scott, F. E. T. (1959). Ann. rheum. Dis., 18, 225 (Differential agglutination titre (DAT) in juvenile rheumatoid arthritis).

- and Scott, F. E. T. (1960). "Rheumatism and the connective tissue diseases", in "Recent Advances in Clinical Pathology", Series III, ed. S. C. Dyke, p. 278. Churchill, London.

Cassidy, J. T., and Valkenburg, H. A. (1967). Arthr. and Rheum., 10, 83 (A five year prospective study of rheumatoid factor tests in juvenile rheumatoid arthritis).

Heller, G., Jacobson, A. S., Kolodny, M. H., and Kammerer, W. H. (1954). J. Immunol., 72, 66 (The hemagglutination test for rheumatoid arthritis. II. The influence of human plasma fraction II (gamma globulin) on the reaction).

Holborow, E. J., and Johnson, G. D. (1967). In "Handbook of Experimental Immunology", ed. D. M. Weir, p. 571. Blackwell Scientific Publications, Oxford.

Jeremy, R., Schaller, J., Arkless, R., Wedgwood, R. J., and Healey, L. A. (1968). Amer. J. Med., 45, 419 (Juvenile rheumatoid arthritis persisting into adulthood).

Laaksonen, A. (1966). Acta paediat. scand., Suppl. 1966 (A prognostic study of juvenile rheumatoid arthritis. Analysis of 544 cases).

Zutshi, D. W., Reading, C. A., Epstein, W. V., Ansell, B. M., and Holborow, E. J. (1969). Ann. rheum. Dis., 28, 289 (FII haemagglutination test for serum antigammaglobulin factors in arthritides sero-positive and sero-negative by other tests). 
Le test d'hémagglutination FII, pour les facteurs de l'antigammaglobuline du sérum dans la maladie de Still

\section{RÉSUMÉ}

Les tests d'hémagglutination FII, de latex et d'agglutination différentielle ont été faits à 286 malades atteints de la maladie bien définie de Still, à 38 atteints de maladie probable de Still et 273 témoins. 26 pour cent des malades atteints de la maladie de Still bien définie avaient des titres FII de 1: 200 ou plus, 15 pour cent étaiant positifs au test de fixation latex et 7 pour cent au test d'agglutination différentielle à $1: 16$ ou plus. Les chiffres correspondants des témoins étaient 18,2 , et 0.4 pour cent. Dans l'arthrite rhumatoïde classique et définie, les chiffres étaient 87,75 , et 42 pour cent respectivement.

La moyenne de titrage FII chez les malades atteints de la maladie de Still était plus élévée d'une manière significative que celle des témoins $(P<0 \cdot 001)$. Cette différence était particulièrement en corrélation avec une maladie active chez les femmes, commençant à un âge plus avancé chez les deux sexes, et avec la présence de nodules et d'érosions.

Une incapacité sérieuse avec la maladie active ou inactive était associée à des titres FII plus élevés. Les cas compliqués de psoriasis, de spondylite ankylosante, d'une affection mono-articulaire au début, d'iridocyclite aigue ou chronique ne montraient aucune augmentation dans les titres à n'importe quel moment. Aucune corrélation nette avec le facteur anti-nucléaire n'a été trouvée excepté chez les malades ayant des nodules.

Il y avait peu de variation dans les titres pendant une période de 6 mois, excepté chez les malades recevant un traitement avec des sels d'or, chez qui le titre FII baissait.
Pruebas de hemaglutinación FII para factores de suero antigamaglobulina en la enfermedad de still

\section{SUMARIO}

Se realizaron pruebas de hemaglutinación FII, de látex y de aglutinación diferencial en 286 pacientes con enfermedad de Still definitiva, 38 con enfermedad de Still "probable", y 273 testigos. En el grupo con enfermedad de Still definitiva un 26 por ciento reveló un título FII de 1: 200 o más, un 15 por ciento arrojó una prueba positiva de fijación de látex, y un 7 por ciento una prueba DAT de 1:16 o más. Las cifras correspondientes en los testigos fueron 18, 2, y 0.4 por ciento. En la poliartritis reumatoide de adultos, clásica y definida, las cifras fueron 87,75 , y 42 por ciento, respectivamente.

El título medio FII en tubo, en pacientes con enfermedad de Still, fue significativamente más alto que en los testigos $(P<0,001)$. Esta diferencia tenía correlación particularmente con la enfermedad activa en mujeres, con la edad adulta al comienzo de la enfermedad en ambos sexos, y con la presencia de nódulos y erosiones.

La incapacidad aguda, en la enfermedad activa o inactiva, fue asociada con títulos FII más elevados. Los casos con soriasis, espondilitis anquilosante, principio monoarticular e iridociclitis aguda o crónica, no mostraron, en ningún momento, incremento en los títulos. No se descrubrió ninguna correlación evidente con el factor antinuclear, excepto en pacientes con nódulos.

Hubo poca variación en los títulos a lo largo de un período de seis meses, excepto en pacientes que estaban recibiendo terapéutica de oro, en los cuales se redujo el título FII. 